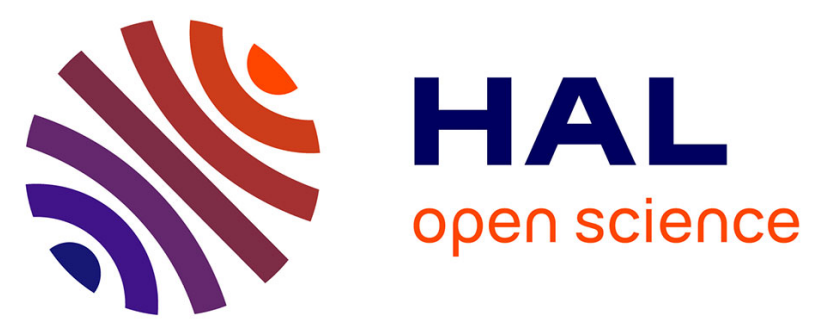

\title{
ALD of ZnO:Ti: Growth Mechanism and Application as an Efficient Transparent Conductive Oxide in Silicon Nanowire Solar Cells
}

Damien Coutancier, Shan-Ting Zhang, Simone Bernardini, Olivier Fournier, Tiphaine Mathieu-Pennober, Frédérique Donsanti, Maria Tchernycheva, Martin Foldyna, Nathanaelle Schneider

\section{To cite this version:}

Damien Coutancier, Shan-Ting Zhang, Simone Bernardini, Olivier Fournier, Tiphaine MathieuPennober, et al.. ALD of ZnO:Ti: Growth Mechanism and Application as an Efficient Transparent Conductive Oxide in Silicon Nanowire Solar Cells. ACS Applied Materials \& Interfaces, 2020, 12, pp.21036 - 21044. 10.1021/acsami.9b22973 . hal-02552636

\section{HAL Id: hal-02552636 \\ https://hal.science/hal-02552636}

Submitted on 4 Jan 2021

HAL is a multi-disciplinary open access archive for the deposit and dissemination of scientific research documents, whether they are published or not. The documents may come from teaching and research institutions in France or abroad, or from public or private research centers.
L'archive ouverte pluridisciplinaire HAL, est destinée au dépôt et à la diffusion de documents scientifiques de niveau recherche, publiés ou non, émanant des établissements d'enseignement et de recherche français ou étrangers, des laboratoires publics ou privés. 


\section{ALD of $\mathrm{ZnO}: \mathrm{Ti}$ : growth mechanism and application}

\section{as efficient transparent conductive oxide in silicon}

\section{nanowire solar cells}

Damien Coutancier, ${ }^{1,2}$ Shan-Ting Zhang, ${ }^{1,2}$ Simone Bernardini, ${ }^{1,3}$ Olivier Fournier, ${ }^{1,4}$ Tiphaine Mathieu-Pennober, ${ }^{5}$ Frédérique Donsanti, ${ }^{1,4}$ Maria Tchernycheva, ${ }^{5}$ Martin Foldyna, ${ }^{6}$ Nathanaelle Schneider ${ }^{*}, 1,2$

${ }^{1}$ Institut Photovoltaïque d'Ile-de-France (IPVF), 18 boulevard Thomas Gobert, 91120 Palaiseau, France

${ }^{2}$ CNRS, UMR 9006, Institut Photovoltaïque d'Ile-de-France (IPVF), 18 boulevard Thomas Gobert, 91120 Palaiseau, France

${ }^{3}$ TOTAL, 18 boulevard Thomas Gobert, 91120 Palaiseau, France

${ }^{4}$ EDF R\&D, IPVF, 18 boulevard Thomas Gobert, 91120 Palaiseau, France

${ }^{5}$ Centre de Nanosciences et de Nanotechnologies, UMR 9001 CNRS, Univ. Paris-Saclay, 10 Boulevard Thomas Gobert, 91120 Palaiseau Cedex, France.

${ }^{6}$ LPICM, CNRS, Ecole Polytechnique, IP Paris, 91128 Palaiseau, France 
KEYWORDS Atomic Layer Deposition, TCO, ZnO:Ti, n-type, QCM studies, silicon nanowire solar cells

\section{ABSTRACT}

In the quest for replacement of indium-tin-oxide (ITO), Ti-doped zinc oxide (TZO) films have been synthesized by atomic layer deposition (ALD) and applied as n-type transparent conductive oxide (TCO). TZO thin films were obtained from titanium (IV) i-propoxide (TTIP), diethyl zinc and water, by introducing $\mathrm{TiO}_{2}$ growth cycle in a $\mathrm{ZnO}$ matrix. Process parameters such as the order of precursor introduction, the cycle ratio and the film thickness were optimized. The as-deposited films were analyzed for their surface morphology, elemental stoichiometry, optoelectronic properties and crystallinity, using a variety of characterization techniques. The growth mechanism was investigated for the first time by in situ quartz-crystal microbalance measurements. It evidenced different insertion modes of titanium depending on the precursor introduction, as well as the etching of Zn-Et surface groups by TTIP. Resistivity as low as $1.2 \times 10^{-3} \Omega \mathrm{cm}$ and transmittance $>80 \%$ in the visible range were obtained for 72-nm thick films. Finally, the first application of ALD-TZO as TCO was reported. TZO films were successfully implemented as top

electrodes in silicon nanowire solar cells. The unique properties of TZO combined with conformal coverage realized by ALD technique make it possible for the cell to show almost flat EQE response, surpassing the bell-like EQE curve seen in devices with sputtered ITO top electrode. 


\section{INTRODUCTION}

Wide band gap oxides have gained great interest as transparent electrode materials in a large range of optoelectronic devices. The most widespread transparent conductive oxide (TCO) is indiumtin-oxide (ITO) due to its superior optoelectronic properties (resistivity $\rho=10^{-4} \Omega \mathrm{cm}$, transparencies $>90 \%) .{ }^{1}$ However, the scarcity of indium and thus the ever-rising price of ITO has urged researchers to develop alternative materials. Zinc oxide $(\mathrm{ZnO})$ is a low-cost wide bandgap $(3.30 \mathrm{eV})$ semiconductor composed of nontoxic and abundant raw materials that can be doped by various elements $(\mathrm{Al}, \mathrm{B}, \mathrm{F}, \mathrm{Ga}, \mathrm{I}, \mathrm{Mg}, \ldots)$, which makes it a promising TCO. ${ }^{2}$ Furthermore, it is equally essential to develop suitable deposition techniques to grow TCO in order to fulfil specific requirements of devices. For example, in terms of nanostructured systems, it is often critical to enable a conformal deposition of TCO materials with a fine control of the film properties (thickness, work function, doping level, etc.) to generate efficient systems.

In particular, the silicon nanowire ( $\mathrm{Si} \mathrm{NW}$ ) solar cells prepared using plasma-assisted vapor-liquidsolid (VLS) growth have been recently introduced in the form of monolithically integrated modules on a single glass substrate. ${ }^{3}$ The module is formed by series connection of multiple cells required for industrial upscaling and it was the first time that the active area of Si NW based radial junction solar module reached $10 \mathrm{~cm}^{2}$. While the large series resistance of first modules has been reduced by depositing a thick ITO top contact followed by a printed dense Ag grid on top, ${ }^{4}$ issues are still to be addressed stemming from the non-conformal ITO deposition and the large shadowing issues caused by the grid. The shadowing induced loss of collected current from areas covered by non-transparent Ag contact, which directly transfers into conversion efficiency loss. A betteradapted solution with a more conformal, and thence conductive, front TCO material is thus highly 
desirable to achieve reduced series resistance and increased transparency, which leads to increased solar cell performance.

Atomic layer deposition (ALD) is well suited for the preparation of n-type wide band gap semiconductors, and has been implemented in various optoelectronic architectures. ${ }^{5,6} \mathrm{By}$ sequentially repeating self-saturated surface reactions, ALD allows growth of uniform and conformal materials with controlled properties under relatively soft conditions. ${ }^{7,8}$ Extensive studies on preparing TCOs by ALD have been reported, which highlights the unique capabilities of ALD. ${ }^{5,6}$ Contrary to materials deposited using conventional methods, ALD-TCOs usually consist of a host matrix with rather dispersed atomic dopants. Such particular arrangement is made possible thanks to the reaction-surface growth mechanism characteristic of the ALD technique and the use of various doping strategies. ${ }^{5,6}$ Both undoped and doped zinc oxide have been extensively investigated by ALD. ${ }^{9,10}$ Typically, diethylzinc (DEZ) and deionized water $\left(\mathrm{H}_{2} \mathrm{O}\right)$ are used as precursors for $\mathrm{Zn}$ and $\mathrm{O}$ atom sources. Doped materials are usually obtained by inserting a dopant growth cycle in between an integer number of $\mathrm{ZnO}$ cycles, leading to what is referred to as an ALD "supercycle". For instance, for ZnO:Al (AZO), the most commonly investigated doped-ZnO material by $\mathrm{ALD},\left\{\mathrm{Al}_{2} \mathrm{O}_{3}\right\}$ dopant cycle are inserted in $\mathrm{ZnO}$ growth. The $\mathrm{Al}$-doping level can be varied by tuning the cycle ratio of $\left\{\mathrm{Al}_{2} \mathrm{O}_{3}\right\}$ with respect to $\{\mathrm{ZnO}\}$. Other parameters reported to affect the doping include the order of precursor introduction, ${ }^{11-13}$ the deposition temperature, ${ }^{14}$ and the pulse or purge duration times. ${ }^{15-17}$ The doping level can also be modified by co-injecting the $\mathrm{Zn}$ and Al precursors, ${ }^{18}$ by using alternative Al precursors ${ }^{19,20}$ or inhibitors. ${ }^{21,22}$ Despite the several advantages of ALD-AZO in terms of synthesis (e.g., relative ease of access to $\left\{\mathrm{Al}_{2} \mathrm{O}_{3}\right\}$ process) and material performances, AZO films often suffer from the presence of inactive dopant atoms or 
$\mathrm{AlO}_{\mathrm{x}}$ phase segregation, and some challenges remain to improve its electrical properties as efficient TCO electrode.

Titanium is another promising dopant atom for $\mathrm{ZnO}$. Compared to $\mathrm{Al}$, Ti has higher valency, thus could potentially provide more charges per atom. The lower growth rate of $\mathrm{TiO}_{2}$ (growth per cycle, $\mathrm{GPC} \sim 0.36 \AA /$ cycle) relative to $\mathrm{Al}_{2} \mathrm{O}_{3}(\mathrm{GPC} \sim 1.3 \AA$ /cycle) can facilitate a better distribution of dopant atoms and thus reduce the formation of undesired $\mathrm{TiO}_{\mathrm{x}}$ nanoprecipates. ${ }^{23}$ Moreover, titanium-doped zinc oxide (TZO) has a higher work function than AZO which for example makes it more suitable as anode for OLED applications. ${ }^{24}$ Compared to AZO, TZO by ALD has been explored to a much smaller extent, ${ }^{23,25-29}$ and so is the Ti-Zn-O system. ${ }^{30-33}$ Most processes for TZO use DEZ, $\mathrm{H}_{2} \mathrm{O}$ and titanium (IV) i-propoxide (TTIP) as precursors, with a supercycle strategy. ${ }^{23,25-27,29}$ The influence of the cycle ratio on the material properties has been previously investigated for different film thicknesses and the optimum range of cycle ratio is reported $\left\{\mathrm{TiO}_{2}\right\}:\{\mathrm{ZnO}\} \sim 1: 10-1: 20 .^{25-27,29}$ Resistivity values as low as $8.9 \times 10^{-4} \Omega \mathrm{cm}$ with high transparencies ( $>80 \%$ ) have been obtained for $100 \mathrm{~nm}$-thick films. ${ }^{23}$ Kim et al. compared AZO and TZO thin films by ALD and they highlighted the advantages of using Ti rather than $\mathrm{Al}$ as dopant, namely lower concentration of inactive dopant, higher electron mobility and higher doping efficiency. ${ }^{23}$ The doping mechanism of TZO has been further investigated by Torrisi et al. ${ }^{28}$ However, except for the effects of the supercycle ratio and the deposition temperature, none of the other reported ALD doping modification methods have been tested on TZO. Also, very little is known on the surface chemistry and growth mechanism of TZO by ALD. Finally, despite its promising properties, to the best of the authors' knowledge, ALD-TZO has never been applied as TCO in real devices. 
The aim of this work is to gain a deeper understanding of the growth mechanism of ALD-TZO as well as to prove its feasibility as TCO in optoelectronic devices, and in particular in Si NW based solar cells by reporting the first application of ALD-TZO thin films as TCO. A thorough investigation of the material growth mechanism by in situ quartz crystal microbalance (QCM) was first carried out to understand the surface chemistry involved and ensure the fine control of the Tidoping in zinc oxide. Subsequently, by tuning the process parameters (i.e. sequence of precursor introduction, cycle ratio, thickness), TZO films with optimized opto-electrical properties were obtained, in line with ones reported in the literature. Finally, the ALD-TZO thin films were applied as transparent electrode materials in Si NW solar cells and were demonstrated not only to work efficiently as TCO material, but also to lead to a superior external quantum efficiency (EQE) response in comparison to ITO.

\section{EXPERIMENTAL SECTION}

\subsection{Material Synthesis}

TZO thin films were prepared in a BENEQ TFS-200 ALD reactor. Diethylzinc $\left(\mathrm{Zn}\left(\mathrm{C}_{2} \mathrm{H}_{5}\right)_{2}\right.$, DEZ, EpiPure, SAFC), titanium (IV) i-propoxide (Ti(OiPr)4, TTIP, min. 98\%, STREM) and deionized water were used as $\mathrm{Zn}, \mathrm{Ti}$, and $\mathrm{O}$ sources, respectively. All chemicals were used without further purification. Nitrogen $\left(\mathrm{N}_{2}, 99.9999 \%\right.$, Air Liquide) was used as both carrier and purging gas. TTIP was heated in a hot solid source system Beneq HS300 at $\mathrm{T}_{\mathrm{TTIP}}=85^{\circ} \mathrm{C}$ while other precursors were kept at room temperature. Experiments were performed at $\mathrm{T}_{\mathrm{dep}}=200{ }^{\circ} \mathrm{C}$ and the pressure in the reaction chamber was kept in the range of $1-2$ mbar. Thin films were deposited simultaneously on borosilicate glass, single- and double-polished n-doped Si (100) wafer with native oxide top layer. Prior to deposition, borosilicate glass substrates were cleaned by ultrasonication in acetone 
and i-propanol (5 min each), while Si (100) substrates were cleaned in a detergent solution (RBS 35 Concentrate, $2 \%$ in water, $5 \mathrm{~min}$ ) and rinsed with deionized water.

TZO film depositions were performed with the following program: $[\mathrm{TZO}]=\mathrm{n} .\left(\mathrm{n}_{1} \cdot\{\mathrm{ZnO}\}+\right.$ $\left.\left\{\mathrm{TiO}_{2}\right\}\right)$ where $\mathrm{n}$ and $\mathrm{n}_{1}$ are the number of supercycles and the ratio of $\mathrm{ZnO}$ and $\mathrm{TiO}_{2}$ cycles $\{\mathrm{ZnO}\}:\left\{\mathrm{TiO}_{2}\right\}$, respectively. The former was varied in a range of values from 22 to 445 whereas for the latter values of $1,2,5,10,20$ were selected. The zinc oxide growth cycle, i.e. $\{\mathrm{ZnO}\}$, was performed according to reported procedure. ${ }^{13}$ Two precursor sequences were investigated and referred to as sequence $A\left(\mathrm{H}_{2} \mathrm{O}\right.$ pulse / $\mathrm{N}_{2}$ purge / DEZ pulse / $\mathrm{N}_{2}$ purge $)$ where the first pulse is a $\mathrm{H}_{2} \mathrm{O}$ pulse; and sequence B (DEZ pulse / $\mathrm{N}_{2}$ purge / $\mathrm{H}_{2} \mathrm{O}$ pulse / $\mathrm{N}_{2}$ purge), where the first pulse is a DEZ pulse. A titanium oxide growth cycle, i.e. $\left\{\mathrm{TiO}_{2}\right\}$, corresponds to $\left\{\mathrm{TiO}_{2}\right\}=$ $\left\{[\right.$ TTIP $\left.] / \mathrm{N}_{2} / \mathrm{H}_{2} \mathrm{O} / \mathrm{N}_{2}=[0.5 / 0.05 / 0.5 / 0.5] / 5 / 2 / 5 \mathrm{~s}\right\}$ and "combination" mode was chosen to ensure proper mass transport of TTIP. "Combination" mode is composed of four steps $\left(\left[\mathrm{t}_{1} / \mathrm{t}_{2} / \mathrm{t}_{3} / \mathrm{t}_{4}\right]\right)$. First, $\mathrm{N}_{2}$ is injected in the TTIP source $\left(\mathrm{t}_{1}\right)$, then all valves are kept closed $\left(\mathrm{t}_{2}\right)$, TTIP precursor is pulsed $\left(t_{3}\right)$. Finally, $\mathrm{N}_{2}$ is injected with simultaneous precursor pulse $\left(\mathrm{t}_{4}\right)$.

\subsection{In-situ Quartz Crystal Microbalance (QCM) measurements}

In-situ QCM measurements were acquired with a Colnatec Eon-LT monitor system, using a HT quartz crystal covered by an aluminum alloy (6 MHz initial oscillation frequency) located on the cover lid of the reactor. Signal was recorded every $0.1 \mathrm{~s}$ and the lowest thickness step precision was $0.04 \AA$ (for pure $\mathrm{ZnO}$ films, the conversion was made with impedance acoustic value $\mathrm{Z}_{\mathrm{f}}=$ 0.556 and $\mathrm{ZnO}$ density of $5.61 \mathrm{~g} / \mathrm{cm}^{3}$ as input parameters). Measurements were done after a stabilization time of 1 hour in order to reach a uniform and constant temperature in the whole reaction chamber $\left(\Delta \mathrm{T} \pm 1.5^{\circ} \mathrm{C}\right)$. To account for the larger reactor volume in QCM configuration 
and ensure an effective saturation state, longer pulse and purge times were chosen. An average over at least five TZO supercycles was performed in order to improve the measurement precision.

\subsection{Material Characterization}

TZO thin film characterization was performed on samples deposited on silicon wafer (ellipsometry, GIXRD, XRR) or borosilicate glass (Raman, Hall effect measurement, spectrophotometry). Thin film thicknesses were determined by spectroscopic ellipsometry (SE) performed with a Horiba Jobin Yvon Uvisel 2 ellipsometer, and X-ray reflectivity (XRR) using a PANalytical Empyrean equipment using $\mathrm{Cu}-\mathrm{K} \alpha$ radiations. For the former, SE measurements in the wavelength range of 200-1700 nm were modelled using a Tauc-Lorentz oscillator function. Xray diffraction (XRD) studies were performed under grazing incidence (GIXRD) conditions for crystallinity determination and phase detection. Thin film compositions and morphologies were obtained using a Merlin VP Compact scanning electron microscope (SEM) provided by Zeiss equipped with an energy dispersive X-Ray spectroscopy (EDS) detector from Bruker. Transmittance and reflectance spectra were obtained using an Agilent Cary 500 UV-Vis-NIR spectrophotometer equipped with an Agilent Diffuse Reflectance accessory. Electrical measurements were performed on samples with an area of $2.25 \mathrm{~cm}^{2}$ at room temperature using four-point probe measurement setup (LucasLab Probe 4 apparatus) and an ECOPIA HMS-5000 system with a $0.556 \mathrm{~T}$ permanent magnet was used for Hall effect measurement. Values of resistivity, carrier concentration, and electron mobility are the average of at least three measurements. Raman spectra were recorded using a Horiba Labram HR spectrometer in the micro-Raman mode (backscattering geometry) at room temperature. A UV laser ( $\lambda=325 \mathrm{~nm}$ ) was used with a power close to $0.04 \mathrm{~mW}$ at the sample surface. 


\subsection{Solar cell device preparation and characterization}

The radial junction solar cells based on silicon nanowires were fabricated on commercial sodalime glass substrate $\left(2.5 \times 2.5 \mathrm{~cm}^{2}\right)$ coated by FTO. The p-type doped Si NWs were grown by plasma-assisted vapor-liquid-solid (VLS) process in plasma-enhanced chemical vapor deposition reactor at substrate temperature of $420{ }^{\circ} \mathrm{C}$. Nanowire arrays were subsequently coated by p-type doped aSi:H followed by an intrinsic aSi:H absorber layer, with the p-i-n junction finished by a thin n-type aSi:H film. The details of the process can be found elsewhere. ${ }^{3}$ The front TCO contact used was either the conventional ITO $(240 \mathrm{~nm})$ deposited by sputtering or ZnO:Ti grown by ALD. The J-V characteristics of the solar cells were measured under standard AM1.5G $\left(100 \mathrm{~mW} / \mathrm{cm}^{2}\right)$ illumination conditions (Newport solar simulator) calibrated using a certified crystalline silicon solar cell. A circular mask with diameter of $4 \mathrm{~mm}$ was used during the measurement to control the illuminated area. The external quantum efficiency (EQE) was measured on an Oriel IQE 200 setup at room temperature.

\section{RESULTS AND DISCUSSION}

\subsection{In situ QCM measurements of TZO during ALD growth}

To optimize the TZO film properties, it is critical to realize a fine tuning of the Ti-doping by controlling the surface chemistry involved during the growth. Mass variations relying on molecule desorption and adsorption during the film deposition have been evidenced by recording in situ QCM measurements.

Figure 1a and Figure 1b display the mass variations of one growth cycle in pure $\mathrm{ZnO}$ and $\mathrm{TiO}_{2}$ films. In case of $\mathrm{ZnO}$ thin films, positive mass variations are recorded after both $\mathrm{H}_{2} \mathrm{O}\left(\Delta \mathrm{m}_{1}{ }^{\mathrm{ZnO}}\right)$ 
and DEZ $\left(\Delta \mathrm{m}_{2}{ }^{\mathrm{ZnO}}\right)$ pulses. As described earlier by Elam et al., this is attributed to the successive surface reactions:

$\mathrm{n}(\mathrm{OH})^{*}+\mathrm{DEZ} \rightarrow \mathrm{n} \mathrm{O}-\mathrm{ZnEt} *+\mathrm{n} \mathrm{C}_{2} \mathrm{H}_{6}$

during the DEZ pulse, and

n O-ZnEt* $+\mathrm{H}_{2} \mathrm{O} \rightarrow \mathrm{n} \mathrm{O}-\mathrm{ZnOH}^{*}+\mathrm{n} \mathrm{C}_{2} \mathrm{H}_{6}$

during the $\mathrm{H}_{2} \mathrm{O}$ pulse, where * represent the surface species and $\mathrm{n}$ the number of hydroxyl groups reacting during each $\{\mathrm{ZnO}\}$ cycle. ${ }^{34}$ The $\mathrm{n}$ value can be determined from the $\left(\Delta \mathrm{m}_{1}{ }^{\mathrm{ZnO}} / \Delta \mathrm{m}_{2}{ }^{\mathrm{ZnO}}\right)$ ratio. In our case $\left(\Delta \mathrm{m}_{1}{ }^{\mathrm{ZnO}} / \Delta \mathrm{m}_{2}{ }^{\mathrm{ZnO}}\right)=0.05$, which corresponds to $\mathrm{n}=1.54$. This is in accordance with reported values $(\mathrm{n}=1.37$ as determined by QCM, $\mathrm{n}=1.56$ as determined by quadrupole mass spectrometry). ${ }^{34,35}$ In case of $\mathrm{TiO}_{2}$ thin films, mass variation is positive after TTIP pulse $\left(\Delta \mathrm{m}_{2}{ }^{\mathrm{TiO} 2}\right)$ and negative after $\mathrm{H}_{2} \mathrm{O}$ pulse $\left(\Delta \mathrm{m}_{1}{ }^{\mathrm{TiO} 2}\right)$. This finding has been attributed to the following surface reactions by Aarik et al.:

$\mathrm{n}(\mathrm{OH})_{\mathrm{n}} *+\mathrm{Ti}(\mathrm{OiPr})_{4} \rightarrow \mathrm{O}-\mathrm{Ti}(\mathrm{OiPr})_{4-\mathrm{n}} *+\mathrm{n} \mathrm{iPrOH}$

during the TTIP pulse, and

$\mathrm{O}-\mathrm{Ti}(\mathrm{OiPr})_{4-\mathrm{n}} *+\mathrm{H}_{2} \mathrm{O} \rightarrow \mathrm{n} \mathrm{O}-\mathrm{TiOH}^{*}+(4-\mathrm{n}) \mathrm{iPrOH}$

during the $\mathrm{H}_{2} \mathrm{O}$ pulse, where * represent the surface species and $\mathrm{n}$ the number of ligand released during the TTIP pulse. ${ }^{36,37}$ The $\mathrm{n}$ value can be determined from the $\left(\Delta \mathrm{m}_{1}{ }^{\mathrm{TiO} 2} / \Delta \mathrm{m}_{2}{ }^{\mathrm{TiO}}\right)$ ratio, and here $\left(\Delta \mathrm{m}_{1}{ }^{\mathrm{TiO} 2} / \Delta \mathrm{m}_{2}{ }^{\mathrm{TiO} 2}\right)=-0.67$. It corresponds to $\mathrm{n}=3.3$, which is slightly higher than reported value $\left(\mathrm{n}=2.2-2.5\right.$ at $\left.\mathrm{T}_{\mathrm{dep}}=200-250^{\circ} \mathrm{C}\right) .{ }^{36}$

The mass variations that occur during the doping cycle $\left\{\mathrm{TiO}_{2}\right\}$ in $\mathrm{ZnO}$, as in TZO films, were recorded. The order of precursor introduction is well-known to impact the surface reactions and thus the film properties. ${ }^{11-13}$ Hence, two sequences were investigated for ZnO: the TTIP pulse follows either a DEZ pulse (sequence A, Figure 1c) or a $\mathrm{H}_{2} \mathrm{O}$ pulse (sequence B, Figure 1d). The 
recorded mass evolutions for both sequences are similar to the case where $\left\{\mathrm{TiO}_{2}\right\}$ grows on itself (Figure 1b). A positive mass variation is observed after the TTIP pulse $\left(\Delta \mathrm{m}_{2}{ }^{\mathrm{TiO} 2}{ }_{-}^{\mathrm{A}}, \Delta \mathrm{m}_{2}{ }^{\mathrm{TiO} 2}{ }_{-} \mathrm{B}\right)$ while a negative one is seen after the $\mathrm{H}_{2} \mathrm{O}$ pulse $\left(\Delta \mathrm{m}_{1}{ }^{\mathrm{TiO} 2}{ }_{-}^{\mathrm{A}}, \Delta \mathrm{m}_{1}{ }^{\mathrm{TiO}}{ }_{-} \mathrm{B}\right)$. However, the ratio

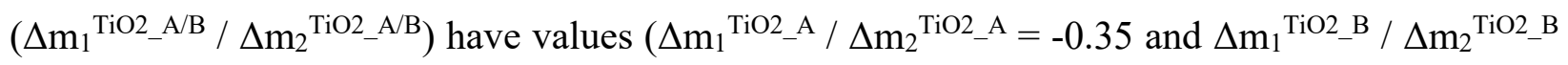
$=-0.37)$ that correspond to different $n$ values than when $\mathrm{TiO}_{2}$ grows on itself $(\mathrm{n}=2.7$ for sequence $\mathrm{A}, \mathrm{n}=2.6$ for sequence $\mathrm{B}$ and $\mathrm{n}=3.3$ for pure $\mathrm{TiO}_{2}$ ). These findings demonstrate that the $\mathrm{TiO}_{2}$ growth is affected by the substrate, as is characteristic of ALD growth. It also shows that the growth of $\mathrm{TiO}_{2}$ is rather hindered upon depositing on the $\mathrm{ZnO}$ surface, as suggested by other groups. ${ }^{23,25,26,31}$ The mass uptakes during the TTIP pulse alone and over the complete $\left\{\mathrm{TiO}_{2}\right\}$ cycle are both larger in sequence $\mathrm{B}$ than in sequence $\mathrm{A}\left(\Delta \mathrm{m}_{2}{ }^{\mathrm{TiO} 2}{ }_{-}^{\mathrm{A}}=0.82\right.$ a.u. vs $\Delta \mathrm{m}_{2}{ }^{\mathrm{TiO} 2}{ }_{-}^{\mathrm{B}}=1.69$ a.u.; $\Delta \mathrm{m}_{1}{ }^{\mathrm{TiO} 2}{ }_{-}^{\mathrm{A}}+\Delta \mathrm{m}_{2}{ }^{\mathrm{TiO} 2}{ }_{-}^{\mathrm{A}}=0.53$ a.u. $v s \Delta \mathrm{m}_{1}{ }^{\mathrm{TiO} 2}{ }_{-}^{\mathrm{B}}+\Delta \mathrm{m}_{2}{ }^{\mathrm{TiO} 2}{ }_{-}^{\mathrm{B}}=1.06$ a.u. $)$. This can be explained by the relative higher reactivity of TTIP towards $\mathrm{Zn}-\mathrm{OH}$ surface species (as in sequence B) than $\mathrm{Zn}$ Et ones (as in sequence A). The mass variation observed in sequence A when TTIP is pulsed on Zn-Et terminated surface can be due to TTIP reacting either with Zn-Et surface groups, remaining -OH surface groups, or both. To discriminate these three possibilities, a specific film deposition sequence was designed: $10 \times\left\{\mathrm{TiO}_{2}\right\} / \mathrm{H}_{2} \mathrm{O}$ pulse / $\mathrm{N}_{2}$ purge / DEZ pulse / $\mathrm{N}_{2}$ purge / $10 \times\left\{\mathrm{TiO}_{2}\right\}$, and the mass variations during the last ten $\left\{\mathrm{TiO}_{2}\right\}$ cycles were recorded and compared (Figure 1e). For all ten cycles, the mass variation is positive during the TTIP pulse. However, the mass gain is negative after the first $\left\{\mathrm{TiO}_{2}\right\}$ cycle, but positive and constant for the following nine cycles. The negative mass gain after the first cycle shows that TTIP reacts and replaces the Zn-Et surface fragments (Ti being lighter than $\mathrm{Zn}$ ). This etching mechanism can be attributed to the higher bond energy of Ti-O vs Zn-O $\left(\mathrm{E}_{\mathrm{Ti}-\mathrm{O}}=666.5 \mathrm{~kJ} \cdot \mathrm{mol}^{-1} v s \mathrm{E}_{\mathrm{Zn}-\mathrm{O}}=159.4 \mathrm{~kJ} \cdot \mathrm{mol}^{-1}\right) \cdot{ }^{38}$ Similar etching can be expected to occur in TZO obtained from sequence A. The fact that a negative mass gain is observed 
after the first cycle (Figure 1e) as compared to a positive mass gain in sequence A (Figure 1c) most likely originates from the difference of the surface and the top layers., When the top layers are $\mathrm{TiO}_{2}$-based (Figure 1e) rather than $\mathrm{ZnO}$-based ( $\mathrm{TZO}$ from sequence A, Figure 1c), the OZnEt bond is weaker hence more reactive and more Zn-Et fragments can be etched by TTIP. In addition to this, the number of remaining hydroxyl groups can be expected to be different, notably due to the surface poisoning effect of iPrOH. ${ }^{39}$ Additional experimental work such as residual gas analysis could provide direct evidence of the etching mechanism. A similar behavior has been reported for ALD-AZO thin films. ${ }^{11,13,19,20,40}$ In summary, different Ti insertion mechanisms following two different precursor sequences are clearly evidenced from the QCM studies, which eventually affects the TZO thin film properties as is discussed in the following section. 

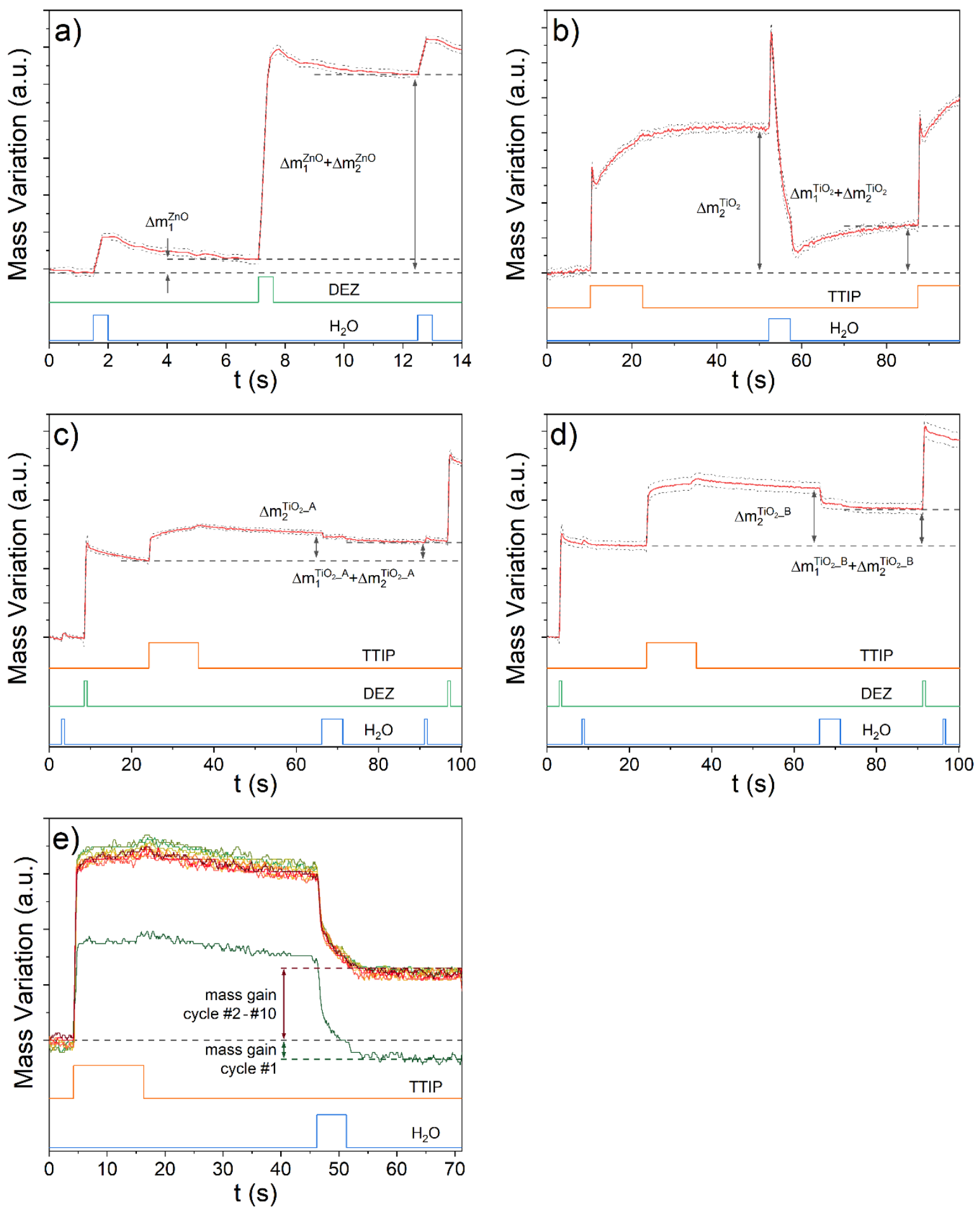
Figure 1. Mass variations recorded by in situ QCM measurements during the growth of (a) pure $\mathrm{ZnO}$ films; (b) pure $\mathrm{TiO}_{2}$ films; (c) $\left\{\mathrm{TiO}_{2}\right\}$ doping cycle in $\mathrm{ZnO}$ (sequence $\mathrm{A}$ ); (d) $\left\{\mathrm{TiO}_{2}\right\}$ doping cycle in $\mathrm{ZnO}$ (sequence B); (e) $10 \times\left\{\mathrm{TiO}_{2}\right\}$ on a substrate composed of $10 \times\left\{\mathrm{TiO}_{2}\right\} / \mathrm{H}_{2} \mathrm{O}$ pulse/ $\mathrm{N}_{2}$ purge / DEZ pulse / $\mathrm{N}_{2}$ purge.

\subsection{Influence of the process parameters on ALD TZO thin film properties}

\subsubsection{Influence of the sequence of precursor introduction}

The order of precursor introduction can have a strong impact not only on the film growth mechanism, but also on its final properties by for example improving the distribution of dopant atoms and reducing the formation of nanolaminate structures, as previously demonstrated for Aldoped $\mathrm{ZnO}$ thin films. ${ }^{11-13}$ Thus, TZO films have been synthesized with two different sequences for the $\{\mathrm{ZnO}\}$ cycle, namely sequence $\mathrm{A}\left(\mathrm{H}_{2} \mathrm{O}\right.$ pulse / $\mathrm{N}_{2}$ purge / DEZ pulse / $\mathrm{N}_{2}$ purge $)$ and sequence $\mathrm{B}$ (DEZ pulse / $\mathrm{N}_{2}$ purge / $\mathrm{H}_{2} \mathrm{O}$ pulse / $\mathrm{N}_{2}$ purge), with constant cycle ratio $\left(\mathrm{n}_{1}=10\right.$ i.e. $\left.\left\{\mathrm{TiO}_{2}\right\}:\{\mathrm{ZnO}\}=1: 10\right)$ and supercycle number $(\mathrm{n}=44)$. The main properties of the obtained films are compared in Table 1, Figure 2, Figure 3 and in Supporting Information (Figure S1).

TZO films grown by both sequences show similar morphology and structural properties. In particular, they are both polycrystalline and adopt the $\mathrm{ZnO}$ würtzite structure. The crystallites have an apparent rice grain shape (average grain size $\sim 80 \mathrm{~nm}$ ), which is different from the round shaped grains of undoped $\mathrm{ZnO}$ (Figure 2), as described elsewhere. ${ }^{27}$ The sequence B leads to thicker films with higher $[\mathrm{Ti}] /[\mathrm{Zn}]$ atomic ratio (as determined from EDS measurements), which is consistent with its higher mass gain observed previously by QCM analysis. In fact, in case of sequence B, the TTIP precursor is pulsed on an OH-terminated surface, which is more reactive than a $\mathrm{Zn}$-Et terminated one, and leads to a higher mass gain over the $\mathrm{TiO}_{2}$ cycle (Figure 1d). The low $\mathrm{Ti}$ content in the film obtained from sequence A confirms the reactivity of TTIP towards Zn-Et 
terminated and/or remaining $-\mathrm{OH}$ surface fragments. In case of sequence $\mathrm{B}$, the measured $[\mathrm{Ti}] /[\mathrm{Zn}]$ atomic ratio equals to $3.1 \mathrm{at} \%$ (Table 1 ), above the solubility limit of Ti in $\mathrm{ZnO}(2 \text { at } \%)^{41}$ This indicates the potential presence of amorphous $\mathrm{TiO}_{2}$ phase at grain boundaries as observed by others via transmission electron microscopy. ${ }^{29}$ Even though sequence B (with higher Ti content) leads to films with a higher carrier concentration $\left(\mathrm{N}=5.5 \times 10^{20} v s 2.5 \times 10^{20} \mathrm{~cm}^{-3}\right)$, it seems that a certain portion of Ti atoms does not act as active dopant but rather as scattering centers, which gives rise to a lower film mobility $\left(\mu=6 v s 20 \mathrm{~cm}^{2} \mathrm{~V}^{-1} \mathrm{~s}^{-1}\right)$. As a consequence, the overall film resistance is higher for sequence $\mathrm{B}$ than for sequence A. In Raman measurement of undoped $\mathrm{ZnO}$, with the resonance UV excitation one identifies the sharp first-order $\mathrm{A}_{1}(\mathrm{LO})$ vibrational modes of würtzite $\mathrm{ZnO}$ located at $575 \mathrm{~cm}^{-1}{ }^{42}$ The broad band on the lower wavenumber region is likely an overlap of several Raman bands such as $\mathrm{E}_{2}^{\text {high }}\left(438 \mathrm{~cm}^{-1}\right.$, first order $), 2 \mathrm{LA}\left(485 \mathrm{~cm}^{-1}\right.$, second order) and so on. ${ }^{42}$ It has been reported that when $\mathrm{ZnO}$ is doped with $\mathrm{Al}$, an additional contribution at around $510 \mathrm{~cm}^{-1}$ appears and the intensity of this defect-related peak is correlated to the conductivity of $\mathrm{ZnO}$ :Al thin films: the more conductive the AZO film, the higher the intensity of the defect-related peak. ${ }^{43,44}$ The same trend is observed here for $\mathrm{ZnO}$ :Ti films as shown in Figure 3a where indeed an additional contribution at $518 \mathrm{~cm}^{-1}$ is clearly visible. The peak intensity is lower for the TZO film of sequence $\mathrm{B}$, which is consistent with its sheet resistance being higher than that of sequence A. Similarly to $\mathrm{ZnO}: \mathrm{Al}$, a red shift of $\mathrm{A}_{1}(\mathrm{LO})$ peak is also observed in $\mathrm{Ti}$ doped $\mathrm{ZnO}$. Both films are equally transparent with transmittance values above $80 \%$ in the 400 $1300 \mathrm{~nm}$ region (Figure 3b), which is in agreement with previously reported ALD-TZO films. ${ }^{23,25-}$ ${ }^{28}$ Finally, as the target properties for a TCO are high transmission and conductivity values, the sequence A was selected for the rest of the study. 
Table 1. Main properties of TZO films obtained from sequences A and B with $n=44$ and $n_{1}=10$.

\begin{tabular}{|c|c|c|c|c|c|}
\hline Sequence & $\begin{array}{c}\text { Thickness } \\
\text { (nm) }\end{array}$ & $\begin{array}{c}\text { Carrier conc. } \\
\left(\mathrm{cm}^{-3}\right)\end{array}$ & $\begin{array}{c}\text { Mobility } \\
\left(\mathrm{cm}^{2} \mathbf{V}^{-1} \mathbf{s}^{-1}\right)\end{array}$ & $\begin{array}{c}\mathbf{R}_{\square} \\
(\mathbf{\Omega} / \mathbf{s q})\end{array}$ & $\begin{array}{l}\text { [Ti]/[Zn] } \\
(\text { at\%)EDS }\end{array}$ \\
\hline $\mathbf{A}$ & 73 & $2.5 \times 10^{20}$ & 20 & 160 & 0.9 \\
\hline B & 82 & $5.5 \times 10^{20}$ & 6 & 295 & 3.1 \\
\hline
\end{tabular}

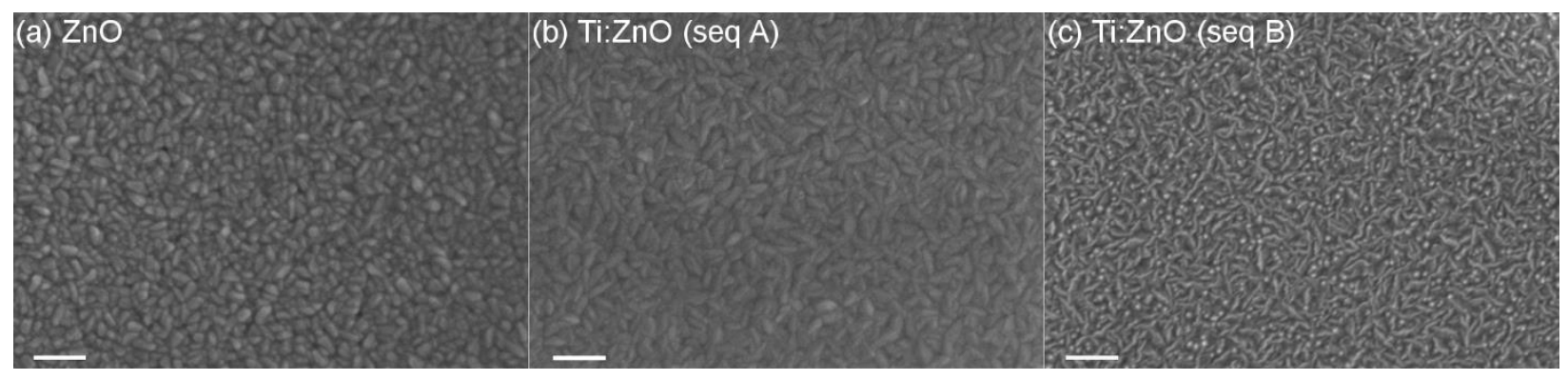

Figure 2. Top SEM images of (a) ZnO, (b) TZO of sequence $\mathrm{A}$ and (c) TZO of sequence B. The scale bar is $100 \mathrm{~nm}$. The film thickness of all three samples are similar, around $80 \mathrm{~nm}$.
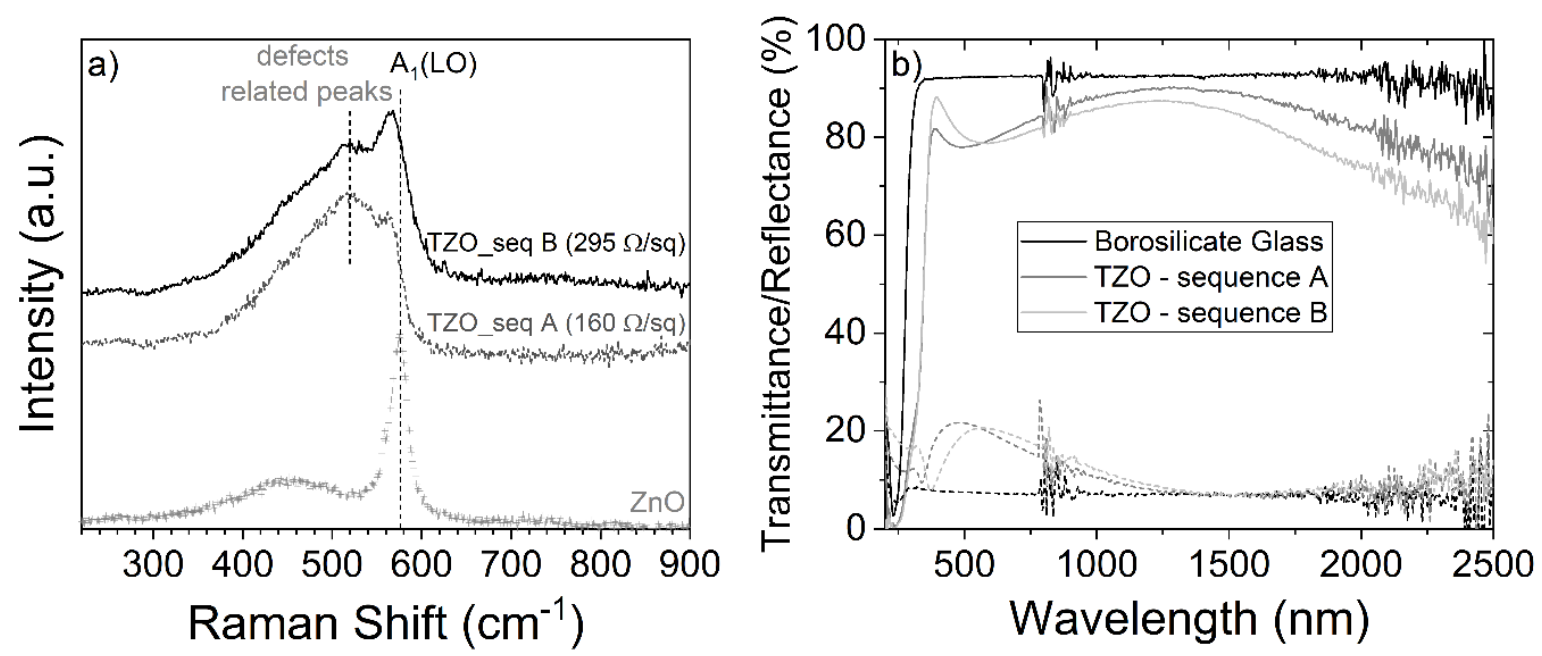

Figure 3. (a) Raman spectra of undoped $\mathrm{ZnO}, \mathrm{TZO}$ of sequence $\mathrm{A}$ and $\mathrm{B}$. The sheet resistance is indicated for $\mathrm{TZO}$ of both sequences while undoped $\mathrm{ZnO}$ is so resistive that its sheet resistance value is not shown. (b) Optical transmittance (solid lines) and reflectance (dotted lines) for the same TZO films of sequence A and B. $\left(\mathrm{n}_{1}=10\right)$ 


\subsubsection{Influence of the cycle ratio $\left\{\mathrm{TiO}_{2}\right\}:\{\mathrm{ZnO}\}$ and the film thickness}

By varying the cycle ratio $\mathrm{n}_{1}\left\{\mathrm{TiO}_{2}\right\}:\{\mathrm{ZnO}\}$ and the number of supercycle $\mathrm{n}$ in $\mathrm{ALD}$, the Ti-doping and thickness of TZO film can be varied, which in turn affects the opto-electrical properties of the resulting TZO films. For TCO materials, the classical Haacke's figure of merit (FoM) is often used to evaluate the overall performance. FoM is defined as: ${ }^{45}$

$$
\text { FoM }=\frac{T^{10}}{R_{\square}}
$$

where $\mathrm{T}$ is the transmittance at $550 \mathrm{~nm}$ and $\mathrm{R}_{\square}$ the sheet resistance. TCOs used in solar cells usually exhibit transmittance of $80 \%$ and sheet resistance of $10 \Omega / \square$, which yields FoM (in unit of $\left.10^{-3} \Omega^{-1}\right)$ of around 10 .

In order to avoid possible formation of $\mathrm{TiO}_{2}$ nanolaminates, ${ }^{7}$ the number of $\left\{\mathrm{TiO}_{2}\right\}$ cycle was kept at 1 while the number of $\{\mathrm{ZnO}\}$ cycles $\left(\mathrm{n}_{1}\right)$ is varied from 1 (high Ti-doping) to 20 (low Ti-doping). As shown in the Supporting Information (Figure S2 - Figure S6), the film thicknesses are lower than the values expected from the linear combination of $\mathrm{GPC}_{\mathrm{TiO} 2}(0.35 \AA /$ cycle $)$ and $\mathrm{GPC}_{\mathrm{ZnO}}(1.68$ $\AA /$ cycle), suggesting that a different growth mechanism is taking place for TZO when compared to pure $\mathrm{ZnO}$ and $\mathrm{TiO}_{2}$. Furthermore, the GPC of TZO films decreases with increasing $\mathrm{Ti}$ incorporation, which highlights a substrate-dependent growth behavior, typical of ALD deposition technique. These findings are in accordance with results previously reported ${ }^{25,26}$ and with our QCM observations. The obtained films have density values in the range of $5.3-5.8 \mathrm{~g} . \mathrm{cm}^{-3}$, which is similar to the $\mathrm{ZnO}$ density. ${ }^{9,10}$ As shown in the Supporting Information (Figure S3), TZO films adopt either a polycrystalline $\mathrm{ZnO}$ würtzite structure $\left(\mathrm{n}_{1} \geq 2\right)$ or a $\mathrm{ZnTiO}_{3}$ nanocrystalline one $\left(\mathrm{n}_{1}\right.$ $=1$ ). ${ }^{31}$ All TZO films are transparent in the visible range (transmittance values above $80 \%$ in the 
$300-1200 \mathrm{~nm}$ region) with optical gap values between 3.2 and $3.7 \mathrm{eV}$, which is in agreement to previously reported results. ${ }^{26}$ The refractive index $n$ at $633 \mathrm{~nm}$ decreases from 2.00 for pure $\mathrm{ZnO}$ to 1.86 for TZO with 1:5 cycle ratio. At higher Ti concentration, the apparent increase of $n$ could indicate the formation of nanoprecipitates of $\mathrm{TiO}_{2} \cdot{ }^{26}$ Finally, all films are n-doped with carrier concentration in the order of $10^{20} \mathrm{~cm}^{-3}$, probably caused by substitutional $\mathrm{Ti}$ and potential $\mathrm{H}$ doping from the precursor. ${ }^{26,46}$ As is seen in Figure 4a, the TZO film prepared with cycle ratio $\left\{\mathrm{TiO}_{2}\right\}:\{\mathrm{ZnO}\}=1: 10$ shows the highest FoM, suggesting that TZO film prepared at this ratio gives the best compromise between optical and electrical properties.

As a consequence, the ratio $\left\{\mathrm{TiO}_{2}\right\}:\{\mathrm{ZnO}\}=1: 10$ was kept the same, while the supercycle numbers were varied from 22 to 82 to grow TZO films of different thicknesses. This resulted in films with a thickness in the range $9-148 \mathrm{~nm}$. A linear growth was observed, with an average GPC value of $1.46 \AA /$ cycle, and almost no nucleation delay was observed (Figure 5). As shown in Supporting Information (Figure S7 - Figure S9), films of all thicknesses are fairly transparent in the visible range, and the optical properties are independent of the film thickness. All films are n-doped and the carrier concentration slightly increases with the film thickness $\left(\mathrm{N}=10^{20}-10^{21} \mathrm{~cm}^{-3}\right)$, as well as the mobility $\left(1-150 \mathrm{~cm}^{2} \mathrm{~V}^{-1} \mathrm{~s}^{-1}\right)$, which is in accordance to previously reported systems. ${ }^{23,25-}$ ${ }^{27,29}$ It seems that thinner films (thickness $<50 \mathrm{~nm}$ ) suffer significantly from the grain boundaries scattering due to the presence of smaller grains. ${ }^{27}$ The resistivity of all films is in the order of $10^{-3}$ $\Omega \mathrm{cm}$; the lowest resistivity value of $5 \times 10^{-4} \Omega \mathrm{cm}$ is seen for $150 \mathrm{~nm}$ thick films, which is slightly more conductive than systems reported by Bergum et al. ${ }^{27}$

Interestingly, the FoM increases monotonically as a function of the film thickness for TZO (Figure 4b). In particular, for the $150 \mathrm{~nm}$ thick TZO film, FoM is fairly close to 10, suggesting that ALDTZO has great potential to be used as a TCO in solar cells. 

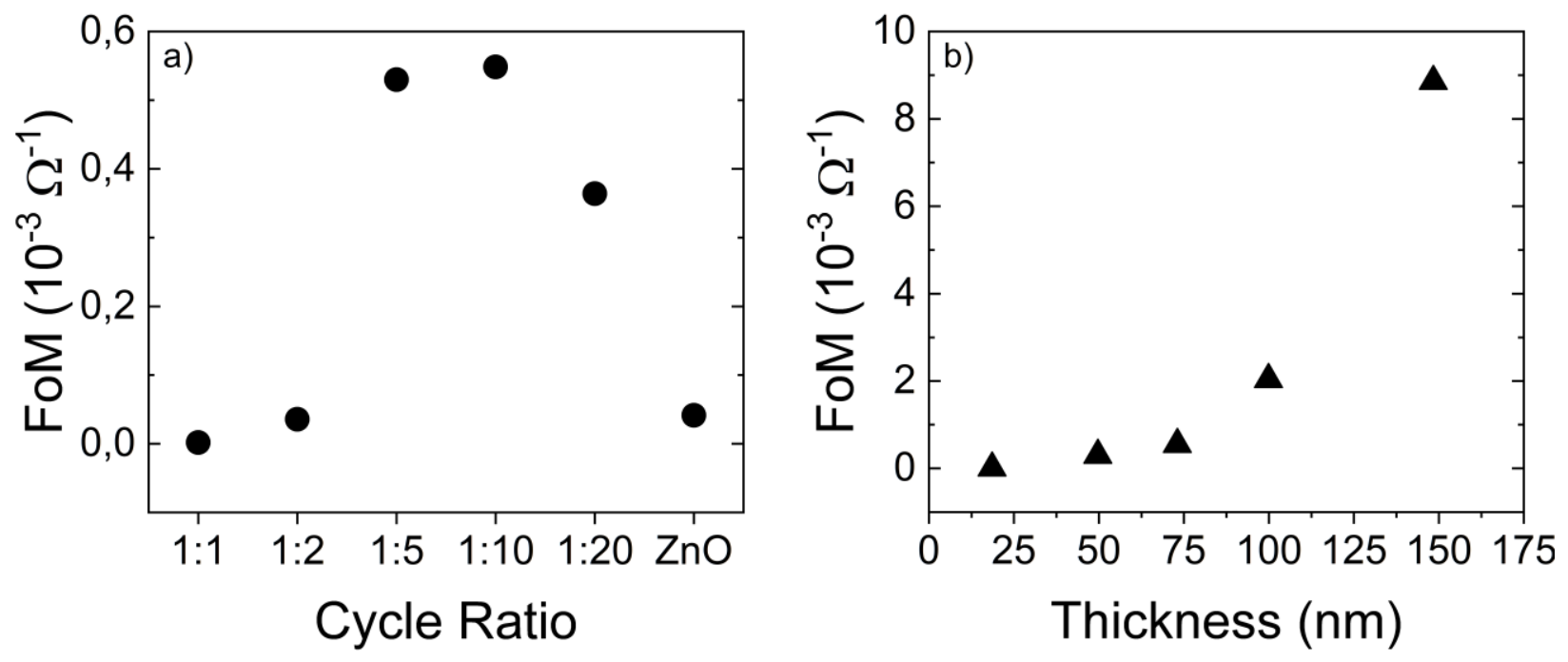

Figure 4. Haacke's figure of merit (FoM, in unit of $\left.10^{-3} \Omega^{-1}\right)$ of TZO films as a function of (a) cycle ratio and (b) film thickness $\left(\mathrm{n}_{1}=10\right)$ during ALD deposition.

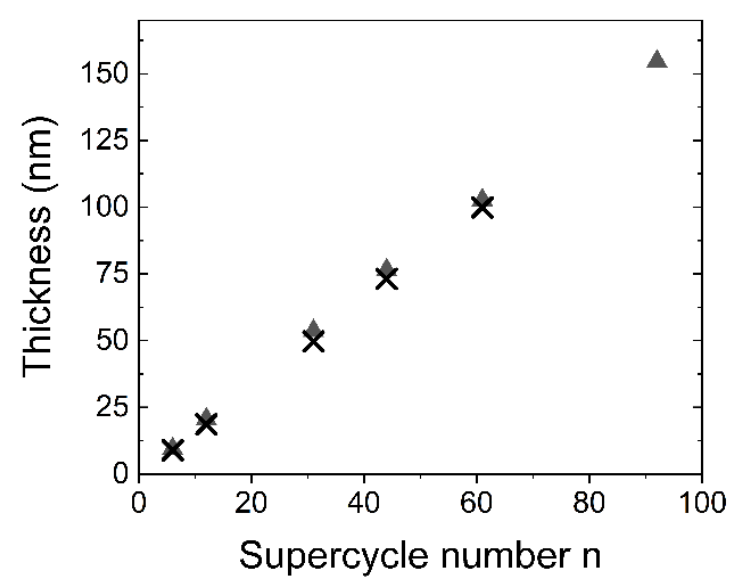

Figure 5. Influence of the supercycle number $n$ on the TZO film thickness, as determined by ellipsometry (triangles) and XRR (crosses) (sequence A, $\mathrm{n}_{1}=10$ ). 


\subsection{Application of ALD-TZO thin films as TCO in Si NW solar cells}

As a reference, sputtered ITO with a nominal thickness of $240 \mathrm{~nm}$ was used as the front TCO in the radial junction Si NWs based solar cells to provide sufficiently low resistance for smaller cell areas with reduced total reflectance. ${ }^{47}$ However, as sputtering utilizes energetic particles, it often results in a directional deposition: ITO deposited on top of the Si NWs is always found thicker than that on the side walls of nanowires (see Figure S10 in Supporting Information). The lack of conformal ITO front contact leads to an inhomogeneous charge collection and increased sheet resistance of the device and thus prevents reaching the maximum final device performance. This drawback can partly be compensated by increasing the ITO thickness which however leads to optical losses.

Therefore, we demonstrate the ALD-TZO thin films for transparent contacts on a proof-of-concept device which can improve the front contact transparency. Silicon NW solar cells with thin amorphous Si absorber and a nanostructured surface morphology, which is particularly challenging for contacting, were chosen for this demonstration. The TCO was deposited on top of solar cells with the following structure: sodalime glass / FTO / p-type c-Si NW / p-type aSi:H / aSi:H absorber layer / n-type aSi:H. The schematic drawing of the structure is shown in Figure 6a. ${ }^{47}$ The corresponding J-V characteristics are shown in Figure 6b. Devices show reasonable series resistance, which validates the ALD-TZO layer as a proper contact film. Despite the efficiency of $2.5 \%$ being relatively low, a photovoltaic diode behavior is clearly seen, suggesting that TZO film by ALD effectively works as a TCO in the nanowire solar cells.

As can be seen in Figure 6d, the external quantum efficiency (EQE) for a cell with sputtered ITO (240 $\mathrm{nm}$ thick) as the front TCO is relatively low $(<70 \%)$ over the visible range. In addition, the 
EQE values are reduced in the wavelength range between 400 and $550 \mathrm{~nm}$, similarly to previously reported devices. ${ }^{47}$ Overall, the EQE response of the ITO-based device exhibits bell-like shape, which is far from ideal. This is caused by the parasitic absorption in the thick ITO contact film. In contrast, the cell coated with an $80 \mathrm{~nm}$ TZO by ALD shows an EQE curve of almost ideal rectangular shape with some losses below the wavelength of $400 \mathrm{~nm}$, thanks to the conformal coverage of TZO over Si NWs as suggested in Figure 6c. In addition, the EQE values are greatly improved to about $80 \%$ over almost the whole visible range. This implies a significant reduction of the parasitic absorptions (due to thick ITO layers) leading to a flat response between 400 and $650 \mathrm{~nm}$ wavelengths, which has been achieved for the first time for VLS-grown Si NW devices. In comparison, the previously best achieved spectral response with sputtered ITO showing larger parasitic losses in the wavelength range below $550 \mathrm{~nm}$ than in this work can be found elsewhere. ${ }^{48}$. The record high EQE values with a very flat response have been achieved for the first time on studied silicon nanowire solar cells. The SiNW devices represent a real challenge for the front transparent contact materials as most of the deposition techniques fail to provide sufficient conformality over the radial junction structure. Our ALD deposited TCO not only covers properly the nanostructured surface, but it also provides superior opto-electrical properties (as shown by EQE) when compared to any previously published results on radial junction devices on a glass substrate. We have demonstrated that using TZO contact layer deposited by ALD technique can significantly improve performance of any flat or (nano-)structured solar cell suffering from the parasitic losses in the front contact. 
(a)
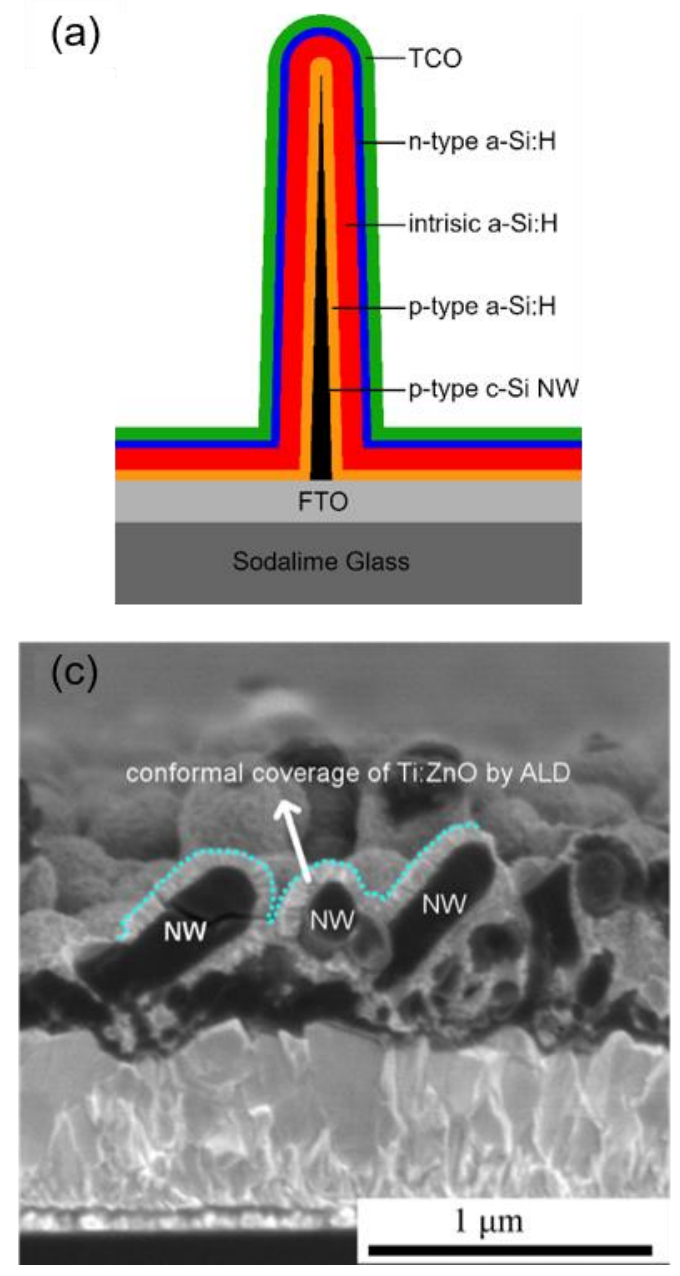
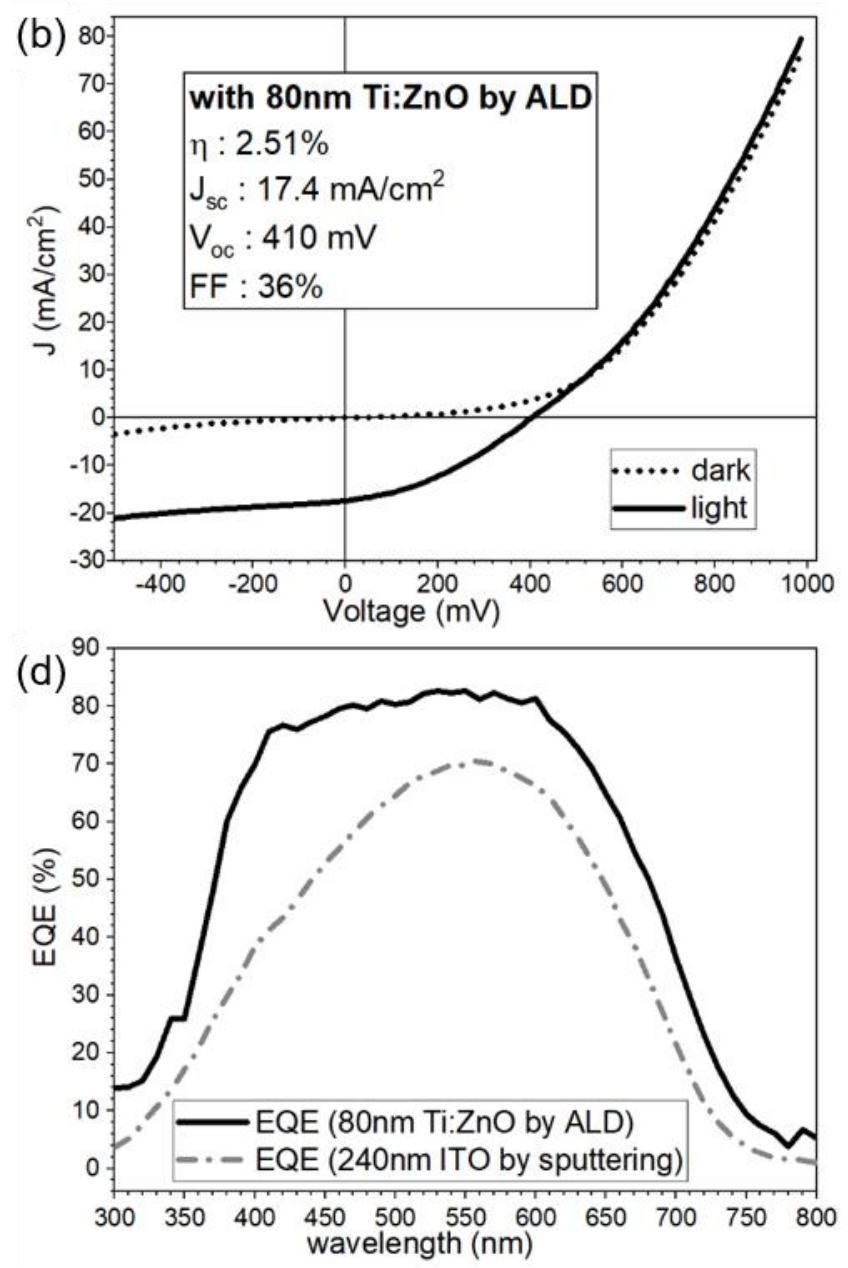

Figure 6. (a) Architecture of radial junction Si NWs solar cells. (b) J-V characteristics of the radial junction Si NW solar cell covered by $80 \mathrm{~nm}$ ZnO:Ti by ALD as front TCO contact. The EQE of the same cell (solid line) is shown in (d) as compared to the EQE curve (dash dot line) measured on a cell with $240 \mathrm{~nm}$ ITO (by sputtering). (c) cross sectional SEM image of the radial NW structure showing conformal coverage by the top ZnO:Ti electrode (by ALD). 


\section{CONCLUSIONS}

Transparent electrode materials are an essential component in most optoelectronic devices. However, nowadays it still remains challenging to develop alternative materials to replace the well-established ITO films using deposition techniques that are well adapted to devices with complex structures. In this context, we report on the growth of titanium-doped zinc oxide (TZO) by atomic layer deposition (ALD), and we demonstrate the successful implementation of TZO as top electrode in silicon nanowire based solar cells.

In this work, TZO films were obtained from diethyl zinc, titanium i-propoxide and water as precursors. Titanium-doping was achieved with a supercycle strategy. We investigated in great details the surface reaction mechanisms during the growth of TZO via in situ quartz crystal microbalance measurements. We verified that the order of the precursors introduction affects the doping mechanism and consequently the final TZO film properties. In particular, sequencedependent surface chemistries, and the capacity of TTIP to replace $-\mathrm{ZnEt}$ terminated surface fragments were demonstrated. Additional parameters such as the cycle ratio and the film thickness were also optimized for TZO films grown by ALD, demonstrating their capacity to tune the TZO properties. Finally, the ALD-TZO thin films were successfully applied as transparent electrode materials in Si NW solar cells. The unique properties of TZO, as well as the conformal deposition ensured by ALD resulted in an almost rectangular shape of the EQE curve of the Si NW device as opposed to the unsatisfactory bell-shaped EQE curve obtained on devices employing an ITO electrode.

In conclusion, ALD-TZO shows great potentials as an efficient top electrode in nanostructured photovoltaic devices and optoelectronic devices in general, and its potential to replace ITO has 
been proven. These findings open the way to many other possible applications of TZO as ITOalternative for optoelectronic devices.

\section{ASSOCIATED CONTENTS}

\section{Supporting Information.}

The Supporting Information is available free of charge. It includes extra characterizations of TZO films, i.e. the influence of the precursor sequence on the structural properties, the influence of the cycle ratio on the film thickness, structural and opto-electrical properties, the influence of the film thickness on the TZO structural properties. It also contains a cross sectional SEM image of the radial NW structure with ITO top electrode.

\section{AUTHOR INFORMATION}

\section{Corresponding Author}

*E-mail: n.schneider@cnrs.fr (N. Schneider)

\section{Funding Sources}

This work was supported by the French Government in the frame of the program of investment for the future (Programme d'Investissement d'Avenir ANR-IEED-002-01), the French Agence Nationale de la Recherche under the contract numbers INDEED ANR-15-CE05-0019 and HANAMI ANR-17-CE09-0022, and the EU ERC project "NanoHarvest" (grant no. 639052).

\section{REFERENCES}

(1) Ginley, D. S.; Perkins, J. D. Transparent Conductors. In Handbook of transparent conductors; Springer, 2011; pp 1-25. 
(2) Transparent Conductive Zinc Oxide: Basics and Applications in Thin Film Solar Cells; Ellmer, K., Klein, A., Rech, B., Eds.; Springer Series in Materials Science; Springer-Verlag: Berlin Heidelberg, 2008. https://doi.org/10.1007/978-3-540-73612-7.

(3) Al-Ghzaiwat, M.; Foldyna, M.; Fuyuki, T.; Chen, W.; Johnson, E. V.; Meot, J.; Roca i Cabarrocas, P. Large Area Radial Junction Silicon Nanowire Solar Mini-Modules. Sci Rep 2018, 8 (1), 1651. https://doi.org/10.1038/s41598-018-20126-5.

(4) Al-Ghzaiwat, M.; Foti, A.; Nuesslein, A.; Halagacka, L.; Meot, J.; Labouret, A.; Ossikovski, R.; Cabarrocas, P. R. i; Foldyna, M. Toward Efficient Radial Junction Silicon Nanowire-Based Solar Mini-Modules. physica status solidi (RRL) - Rapid Research Letters 2019, 13 (2), 1800402. https://doi.org/10.1002/pssr.201800402.

(5) Leskelä, M.; Mattinen, M.; Ritala, M. Review Article: Atomic Layer Deposition of Optoelectronic Materials. Journal of Vacuum Science \& Technology B 2019, 37 (3), 030801. https://doi.org/10.1116/1.5083692.

(6) Sheng, J.; Lee, J.-H.; Choi, W.-H.; Hong, T.; Kim, M.; Park, J.-S. Review Article: Atomic Layer Deposition for Oxide Semiconductor Thin Film Transistors: Advances in Research and Development. Journal of Vacuum Science \& Technology A 2018, 36 (6), 060801. https://doi.org/10.1116/1.5047237.

(7) George, S. M. Atomic Layer Deposition: An Overview. Chemical Reviews 2010, 110 (1), 111-131. https://doi.org/10.1021/cr900056b.

(8) Miikkulainen, V.; Nilsen, O.; Li, H.; King, S. W.; Laitinen, M.; Sajavaara, T.; Fjellvåg, H. Atomic Layer Deposited Lithium Aluminum Oxide: (In)Dependency of Film Properties from Pulsing Sequence. Journal of Vacuum Science \& Technology A 2015, 33 (1), 01A101. https://doi.org/10.1116/1.4890006.

(9) Gao, Z.; Banerjee, P. Review Article: Atomic Layer Deposition of Doped ZnO Films. Journal of Vacuum Science \& Technology A 2019, 37 (5), 050802. https://doi.org/10.1116/1.5112777.

(10) Tynell, T.; Karppinen, M. Atomic Layer Deposition of ZnO: A Review. Semiconductor Science and Technology 2014, 29 (4), 043001. https://doi.org/10.1088/0268-1242/29/4/043001.

(11) Na, J.-S.; Peng, Q.; Scarel, G.; Parsons, G. N. Role of Gas Doping Sequence in Surface Reactions and Dopant Incorporation during Atomic Layer Deposition of Al-Doped ZnO. Chem. Mater. 2009, 21 (23), 5585-5593. https://doi.org/10.1021/cm901404p.

(12) Pollock, E. B.; Lad, R. J. Influence of Dosing Sequence and Film Thickness on Structure and Resistivity of Al-ZnO Films Grown by Atomic Layer Deposition. Journal of Vacuum Science \& Technology A 2014, 32 (4), 041516. https://doi.org/10.1116/1.4885063.

(13) Le Tulzo, H.; Schneider, N.; Lincot, D.; Patriarche, G.; Donsanti, F. Impact of the Sequence of Precursor Introduction on the Growth and Properties of Atomic Layer Deposited AlDoped ZnO Films. Journal of Vacuum Science \& Technology A 2018, 36 (4), 041502. https://doi.org/10.1116/1.5030990. 
(14) Ahn, C. H.; Lee, S. Y.; Cho, H. K. Influence of Growth Temperature on the Electrical and Structural Characteristics of Conductive Al-Doped ZnO Thin Films Grown by Atomic Layer Deposition. Thin Solid Films 2013, 545, 106-110. https://doi.org/10.1016/j.tsf.2013.07.045.

(15) Lee, D.-J.; Kwon, J.-Y.; Kim, S.-H.; Kim, H.-M.; Kim, K.-B. Effect of Al Distribution on Carrier Generation of Atomic Layer Deposited Al-Doped ZnO Films. J. Electrochem. Soc. 2011, 158 (5), D277-D281. https://doi.org/10.1149/1.3568881.

(16) Genevée, P.; Donsanti, F.; Renou, G.; Lincot, D. Study of the Aluminum Doping of Zinc Oxide Films Prepared by Atomic Layer Deposition at Low Temperature. Applied Surface Science 2013, 264, 464-469. https://doi.org/10.1016/j.apsusc.2012.10.045.

(17) Park, H. K.; Yang, B. S.; Park, S.; Kim, M. S.; Shin, J. C.; Heo, J. Purge-Time-Dependent Growth of ZnO Thin Films by Atomic Layer Deposition. Journal of Alloys and Compounds 2014, 605, 124-130. https://doi.org/10.1016/j.jallcom.2014.03.169.

(18) Yuan, H.; Luo, B.; Yu, D.; Cheng, A.; Campbell, S. A.; Gladfelter, W. L. Atomic Layer Deposition of Al-Doped ZnO Films Using Ozone as the Oxygen Source: A Comparison of Two Methods to Deliver Aluminum. Journal of Vacuum Science \& Technology A 2011, 30 (1), 01 A138. https://doi.org/10.1116/1.3666030.

(19) Wu, Y.; Potts, S. E.; Hermkens, P. M.; Knoops, H. C. M.; Roozeboom, F.; Kessels, W. M. M. Enhanced Doping Efficiency of Al-Doped $\mathrm{ZnO}$ by Atomic Layer Deposition Using Dimethylaluminum Isopropoxide as an Alternative Aluminum Precursor. Chem. Mater. 2013. https://doi.org/10.1021/cm402974j.

(20) Qian, X.; Cao, Y.; Guo, B.; Zhai, H.; Li, A. Atomic Layer Deposition of Al-Doped ZnO Films Using Aluminum Isopropoxide as the Al Precursor. Chemical Vapor Deposition 2013, 19 (4-6), 180-185. https://doi.org/10.1002/cvde.201207051.

(21) Yanguas-Gil, A.; Peterson, K. E.; Elam, J. W. Controlled Dopant Distribution and Higher Doping Efficiencies by Surface-Functionalized Atomic Layer Deposition. Chem. Mater. 2011, 23 (19), 4295-4297. https://doi.org/10.1021/cm2014576.

(22) Yanguas-Gil, A.; Libera, J. A.; Elam, J. W. Modulation of the Growth Per Cycle in Atomic Layer Deposition Using Reversible Surface Functionalization. Chem. Mater. 2013, 25 (24), 48494860. https://doi.org/10.1021/cm4029098.

(23) Lee, D.-J.; Kim, K.-J.; Kim, S.-H.; Kwon, J.-Y.; Xu, J.; Kim, K.-B. Atomic Layer Deposition of Ti-Doped ZnO Films with Enhanced Electron Mobility. J. Mater. Chem. C 2013, 1 (31), 4761-4769. https://doi.org/10.1039/C3TC30469H.

(24) Tseng, Z.-L.; Kao, P.-C.; Yang, C.-S.; Juang, Y.-D.; Kuo, Y.-M.; Chu, S.-Y. Transparent Conducting Ti-Doped ZnO Thin Films Applied to Organic Light-Emitting Diodes. J. Electrochem. Soc. 2011, 158 (5), J133. https://doi.org/10.1149/1.3554730.

(25) Ye, Z.-Y.; Lu, H.-L.; Geng, Y.; Gu, Y.-Z.; Xie, Z.-Y.; Zhang, Y.; Sun, Q.-Q.; Ding, S.-J.; Zhang, D. W. Structural, Electrical, and Optical Properties of Ti-Doped ZnO Films Fabricated by 
Atomic Layer Deposition. Nanoscale Res Lett 2013, 8 (1), 108. https://doi.org/10.1186/1556276X-8-108.

(26) Bergum, K.; Hansen, P.-A.; Fjellvåg, H.; Nilsen, O. Structural, Electrical and Optical Characterization of Ti-Doped ZnO Films Grown by Atomic Layer Deposition. Journal of Alloys and Compounds 2014, 616, 618-624. https://doi.org/10.1016/j.jallcom.2014.07.177.

(27) Bergum, K.; Fjellvåg, H.; Nilsen, O. Thickness Dependent Structural, Optical and Electrical Properties of Ti-Doped ZnO Films Prepared by Atomic Layer Deposition. Applied Surface Science 2015, 332, 494-499. https://doi.org/10.1016/j.apsusc.2015.01.124.

(28) Torrisi, G.; Mauro, A. D.; Scuderi, M.; Nicotra, G.; Impellizzeri, G. Atomic Layer Deposition of $\mathrm{ZnO} / \mathrm{TiO} 2$ Multilayers: Towards the Understanding of Ti-Doping in $\mathrm{ZnO}$ Thin Films. RSC Adv. 2016, 6 (91), 88886-88895. https://doi.org/10.1039/C6RA13773C.

(29) Wan, Z.; Kwack, W.-S.; Lee, W.-J.; Jang, S.-I.; Kim, H.-R.; Kim, J.-W.; Jung, K.-W.; Min, W.-J.; Yu, K.-S.; Park, S.-H.; Yun, E.-Y.; Kim, J.-H.; Kwon, S.-H. Electrical and Optical Properties of Ti Doped ZnO Films Grown on Glass Substrate by Atomic Layer Deposition. Materials Research Bulletin 2014, 57, 23-28. https://doi.org/10.1016/j.materresbull.2014.04.070.

(30) Borgese, L.; Bontempi, E.; Depero, L. E.; Colombi, P.; Alessandri, I. Tailoring Phase and Composition at the Nanoscale: Atomic Layer Deposition of Zn-Ti-O Thin Films. CrystEngComm 2011, 13 (22), 6621-6624. https://doi.org/10.1039/C1CE05923H.

(31) Qian, X.; Gao, M.-Y.; Cao, Y.-Q.; Guo, B.-L.; Li, A.-D. Preparation and Phase Structures of $\mathrm{Zn}-\mathrm{Ti}-\mathrm{O}$ Ternary Compounds by Atomic Layer Deposition. Journal of Vacuum Science \& Technology A 2012, 31 (1), 01A133. https://doi.org/10.1116/1.4769451.

(32) Löckinger, J.; Nishiwaki, S.; Andres, C.; Erni, R.; Rossell, M. D.; Romanyuk, Y. E.; Buecheler, S.; Tiwari, A. N. ALD-ZnxTiyO as Window Layer in $\mathrm{Cu}(\mathrm{In}, \mathrm{Ga}) \mathrm{Se} 2$ Solar Cells. ACS Appl. Mater. Interfaces 2018, 10 (50), 43603-43609. https://doi.org/10.1021/acsami.8b14490.

(33) Hwang, S.; Larina, L.; Lee, H.; Kim, S.; Choi, K. S.; Jeon, C.; Ahn, B. T.; Shin, B. Wet Pretreatment-Induced Modification of $\mathrm{Cu}(\mathrm{In}, \mathrm{Ga}) \mathrm{Se} 2 / \mathrm{Cd}-$ Free ZnTiO Buffer Interface. ACS Appl. Mater. Interfaces 2018, 10 (24), 20920-20928. https://doi.org/10.1021/acsami.8b01090.

(34) Elam, J. W.; George, S. M. Growth of ZnO/Al2O3 Alloy Films Using Atomic Layer Deposition Techniques. Chem. Mater. 2003, $15 \quad$ (4), 1020-1028. https://doi.org/10.1021/cm020607+.

(35) Gao, Z.; Wu, F.; Myung, Y.; Fei, R.; Kanjolia, R.; Yang, L.; Banerjee, P. Standing and Sitting Adlayers in Atomic Layer Deposition of ZnO. Journal of Vacuum Science \& Technology A 2015, 34 (1), 01A143. https://doi.org/10.1116/1.4938080.

(36) Aarik, J.; Aidla, A.; Uustare, T.; Ritala, M.; Leskelä, M. Titanium Isopropoxide as a Precursor for Atomic Layer Deposition: Characterization of Titanium Dioxide Growth Process. Applied Surface Science 2000, 161 (3), 385-395. https://doi.org/10.1016/S0169-4332(00)002749. 
(37) Rahtu, A.; Ritala, M. Reaction Mechanism Studies on Titanium Isopropoxide-Water Atomic Layer Deposition Process. Chemical Vapor Deposition 2002, 8 (1), 21-28. https://doi.org/10.1002/1521-3862(20020116)8:1<21::AID-CVDE21>3.0.CO;2-0.

(38) Luo, Y.-R. Comprehensive Handbook of Chemical Bond Energies; CRC Press, 2007. https://doi.org/10.1201/9781420007282.

(39) Ritala, M.; Leskela, M.; Niinisto, L.; Haussalo, P. Titanium Isopropoxide as a Precursor in Atomic Layer Epitaxy of Titanium Dioxide Thin Films. Chem. Mater. 1993, 5 (8), 1174-1181. https://doi.org/10.1021/cm00032a023.

(40) Elam, J. ZnO/A12O3 Nanolaminates Fabricated by Atomic Layer Deposition: Growth and Surface Roughness Measurements. Thin Solid Films 2002, 414 (1), 43-55. https://doi.org/10.1016/S0040-6090(02)00427-3.

(41) Singh, S.; Rama, N.; Sethupathi, K.; Rao, M. S. R. Correlation between Electrical Transport, Optical, and Magnetic Properties of Transition Metal Ion Doped ZnO. Journal of Applied Physics 2008, 103 (7), 07D108. https://doi.org/10.1063/1.2834443.

(42) Cuscó, R.; Alarcón-Lladó, E.; Ibáñez, J.; Artús, L.; Jiménez, J.; Wang, B.; Callahan, M. J. Temperature Dependence of Raman Scattering in ZnO. Phys. Rev. B 2007, 75 (16), 165202. https://doi.org/10.1103/PhysRevB.75.165202.

(43) Insignares-Cuello, C.; Fontané, X.; Sánchez-González, Y.; Placidi, M.; Broussillou, C.; López-García, J.; Saucedo, E.; Bermúdez, V.; Pérez-Rodríguez, A.; Izquierdo-Roca, V. NonDestructive Assessment of $\mathrm{ZnO}: \mathrm{Al}$ Window Layers in Advanced $\mathrm{Cu}(\mathrm{In}, \mathrm{Ga}) \mathrm{Se}{ }_{2}$ Photovoltaic Technologies: ZnO:Al Window Layers in Advanced $\mathrm{Cu}(\mathrm{In}, \mathrm{Ga}) \mathrm{Se}_{2} \mathrm{PV}$ Technologies. Phys. Status Solidi A 2015, 212 (1), 56-60. https://doi.org/10.1002/pssa.201431222.

(44) Guc, M.; Tsin, F.; Rousset, J.; Romanyuk, Y. E.; Izquierdo-Roca, V.; Pérez-Rodríguez, A. Nondestructive Raman Scattering Assessment of Solution-Processed ZnO-Doped Layers for Photovoltaic Applications. J. Phys. Chem. C 2017, 121 (6), 3212-3218. https://doi.org/10.1021/acs.jpcc.6b11525.

(45) Haacke, G. New Figure of Merit for Transparent Conductors. Journal of Applied Physics 1976, 47 (9), 4086-4089. https://doi.org/10.1063/1.323240.

(46) Yong, Z.; Liu, T.; Uruga, T.; Tanida, H.; Qi, D.; Rusydi, A.; Wee, A. T. S. Ti-Doped ZnO Thin Films Prepared at Different Ambient Conditions: Electronic Structures and Magnetic Properties. Materials 2010, 3 (6), 3642-3653. https://doi.org/10.3390/ma3063642.

(47) Misra, S.; Yu, L.; Foldyna, M.; Roca i Cabarrocas, P. High Efficiency and Stable Hydrogenated Amorphous Silicon Radial Junction Solar Cells Built on VLS-Grown Silicon Nanowires. Solar Energy Materials and Solar Cells 2013, 118, 90-95. https://doi.org/10.1016/j.solmat.2013.07.036.

(48) Misra, S.; Yu, L.; Foldyna, M.; Roca i Cabarrocas, P. New Approaches to Improve the Performance of Thin-Film Radial Junction Solar Cells Built Over Silicon Nanowire Arrays. IEEE Journal of Photovoltaics 2015, 5 (1), 40-45. https://doi.org/10.1109/JPHOTOV.2014.2366688. 


\section{TABLE OF CONTENTS (TOC) GRAPHIC}

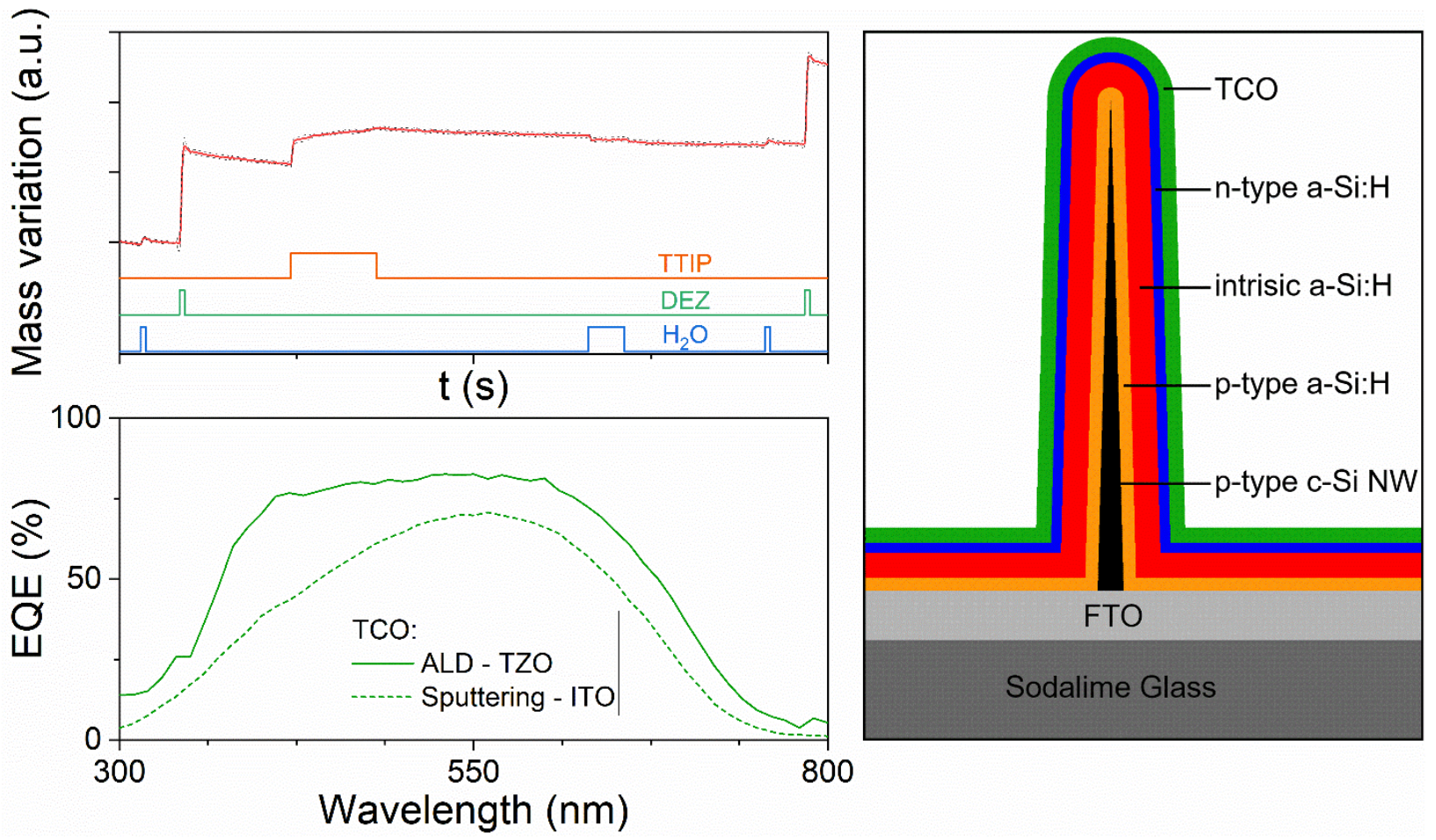

